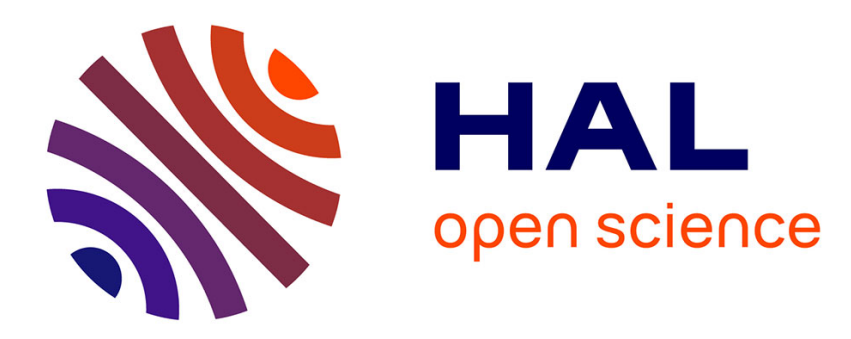

\title{
XAFS Study of Fe Intercalated Fullerite
}

E. Sobczak, R. Nietubyc, A. Traverse, D. Zymierska, Y. Swilem, P. Byszewski

\section{To cite this version:}

E. Sobczak, R. Nietubyc, A. Traverse, D. Zymierska, Y. Swilem, et al.. XAFS Study of Fe Intercalated Fullerite. Journal de Physique IV Proceedings, 1997, 7 (C2), pp.C2-1235-C2-1236. 10.1051/jp4:19972210 . jpa-00255283

\section{HAL Id: jpa-00255283 https://hal.science/jpa-00255283}

Submitted on 1 Jan 1997

HAL is a multi-disciplinary open access archive for the deposit and dissemination of scientific research documents, whether they are published or not. The documents may come from teaching and research institutions in France or abroad, or from public or private research centers.
L'archive ouverte pluridisciplinaire HAL, est destinée au dépôt et à la diffusion de documents scientifiques de niveau recherche, publiés ou non, émanant des établissements d'enseignement et de recherche français ou étrangers, des laboratoires publics ou privés. 


\title{
XAFS Study of Fe Intercalated Fullerite
}

\author{
E. Sobczak, R. Nietubyc, A. Traverse*, D. Żymierska, Y. Swilem and P. Byszewski \\ Institute of Physics P.A.S., Al. Lotników 36/42, 02-668 Warsaw, Poland \\ * LURE, Centre Universitaire Paris-Sud, 91405 Orsay cedex, France
}

\begin{abstract}
Fe $\mathrm{K}$ edge XANES and EXAFS studies were performed to reveal the local structure around $\mathrm{Fe}$ ions in $\mathrm{C}_{60} \mathrm{Fe}_{2}$ fullerites. The measurements were carried out in transmission mode at $\mathrm{LN}_{2}$ temperature for the monoclinic and fcc $\mathrm{C}_{60} \mathrm{Fe}_{2}$ fullerite powder samples and other materials: ferrocene $\mathrm{Fe}\left(\mathrm{C}_{5} \mathrm{H}_{5}\right)_{2}$, Fe metal foil and $\alpha-\mathrm{Fe}_{2} \mathrm{O}_{3}$. The XAFS spectra of the monoclinic $\mathrm{C}_{60} \mathrm{Fe}_{2}$ fullerite is almost identical to that of ferrocen. The XAFS spectra of the fcc $\mathrm{C}_{60} \mathrm{Fe}_{2}$ fullerite have shown that Fe neutral atoms, $\mathrm{Fe}^{2+}$ and $\mathrm{Fe}^{3+}$ ions appear in this fullerite due to annealing at temperature $850 \mathrm{~K}$. The EXAFS study has proved the presence of small Fe clusters in this form of fullerite.
\end{abstract}

\section{INTRODUCTION}

The discovery of fullerenes in 1985 and their production in macroscopic scale in 1990 have created new research and applications perspectives. The molecule of fullerene, e.g., $\mathrm{C}_{60}$, may play role of an "artificial atom". These artificial atoms can be used together with ordinary atoms to construct new materials. In our opinion, the case of transition metal intercalated fullerite is very interesting because new forms of solid-state materials can be synthesized, possibly with important physical and chemical properties. The aim of present paper is to determine a local structure around Fe ions in Fe intercalated fullerites. The Fe K edge X-ray absorption spectroscopy using synchrotron radiation was chosen as the most suitable technique for this purpose.

\section{EXPERIMENTAL}

$\mathrm{C}_{60} \mathrm{Fe}_{2}$ fullerite in a powder form was obtained by decomposition of ferrocene $\mathrm{Fe}\left(\mathrm{C}_{5} \mathrm{H}_{5}\right)_{2}$ at temperatures ranging from $570 \mathrm{~K}$ to $640 \mathrm{~K}$ in solid fullerite [1]. The reaction probably consists on a substitution of ligands in ferrocene by fullerenes. In order to remove residuals of nonreactive ferrocene, after the reaction the sample was annealed in vacuum at temperature $600 \mathrm{~K}$, which is above the decomposition temperature of $\mathrm{C}_{60}\left[\mathrm{Fe}\left(\mathrm{C}_{5} \mathrm{H}_{5}\right)_{2}\right]_{2}$. The $\mathrm{C}_{60} \mathrm{Fe}_{2}$ fullerite has the monoclinic structure with lattice parameters $\mathrm{a}=24.3 \AA, \mathrm{b}=12.6 \AA, \mathrm{c}=17.1 \AA$ and $\beta=97^{\circ}$. It is supposed that the ferrocene-like bonds in a bridge $\mathrm{C}_{60} \mathrm{FeC}_{60}$ are formed between $\mathrm{Fe}$ ions and carbon pentagons.

The fcc $\mathrm{C}_{60} \mathrm{Fe}_{2}$ fullerite with lattice constant $\mathrm{a}=14.2 \AA$ was obtained from the monoclinic $\mathrm{C}_{60} \mathrm{Fe}_{2}$ fullerite by annealing in temperature range $720-850 \mathrm{~K}[1,2]$. This irreversible exothermic transition was examined by the differential scanning calorimetry method. The Mössbauer spectroscopy proved that during high temperature treatment part of iron atoms adopt $\mathrm{Fe}^{3+}$ ionization state in the $\mathrm{fcc} \mathrm{C}_{60} \mathrm{Fe}_{2}$ fullerite [3].

The experiment was performed at the station XAS1 of the synchrotron radiation laboratory LURE in Orsay. The $\mathrm{Si}$ channel-cut monochromator and (33I) reflection was used. The $\mathrm{Fe}-\mathrm{K}$ absorption spectra for the monoclinic and fcc $\mathrm{C}_{60} \mathrm{Fe}_{2}$ fullerites, ferrocene, $\alpha-\mathrm{Fe}_{2} \mathrm{O}_{3}$ powders and $\mathrm{Fe}$ metal were recorded in transmission mode at liquid nitrogen temperature.

\section{RESULTS AND DISCUSSION}

After normalization at $7175 \mathrm{eV}$, the $\mathrm{XANES}$ spectra are shown in Fig. 1a. The absorption edge for the monoclinic $\mathrm{C}_{60} \mathrm{Fe}_{2}$ fullerite is almost identical to that for ferrocene, but more sharp. We believe that it is due to high symmetry of carbon pentagons in fulleren $\mathbf{C}_{60}$ molecule in comparison to the distorted cyclopentadienyl rings in ferrocene. Our results are in a good agreement with the Mössbauer studies [3], which indicated that the iron ion in the monoclinic $\mathrm{C}_{60} \mathrm{Fe}_{2}$ is in the state $\mathrm{Fe}^{+2}$ with quadrupole splitting similar to that of ferrocene. The shape of the XANES spectrum for the fcc $\mathrm{C}_{60} \mathrm{Fe}_{2}$ is distinguished from that for the monoclinic $\mathrm{C}_{60} \mathrm{Fe}_{2}$ fullerite. We have fitted the shape of this absorption edge in range up to $7140 \mathrm{eV}$ as weighted sum of absorption edges for $\mathrm{Fe}$ neutral atoms ( $\mathrm{Fe}$ foil), $\mathrm{Fe}^{2+}$ ions (monoclinic $\mathrm{C}_{60} \mathrm{Fe}_{2}$ ) and $\mathrm{Fe}^{3+}$ ions $\left(\mathrm{Fe}_{2} \mathrm{O}_{3}\right)$. The best fit was achieved for contributions of $24 \% \mathrm{Fe}$ neutral atoms, $40 \% \mathrm{Fe}^{2+}$ ions and $36 \% \mathrm{Fe}^{3+}$ ions. 

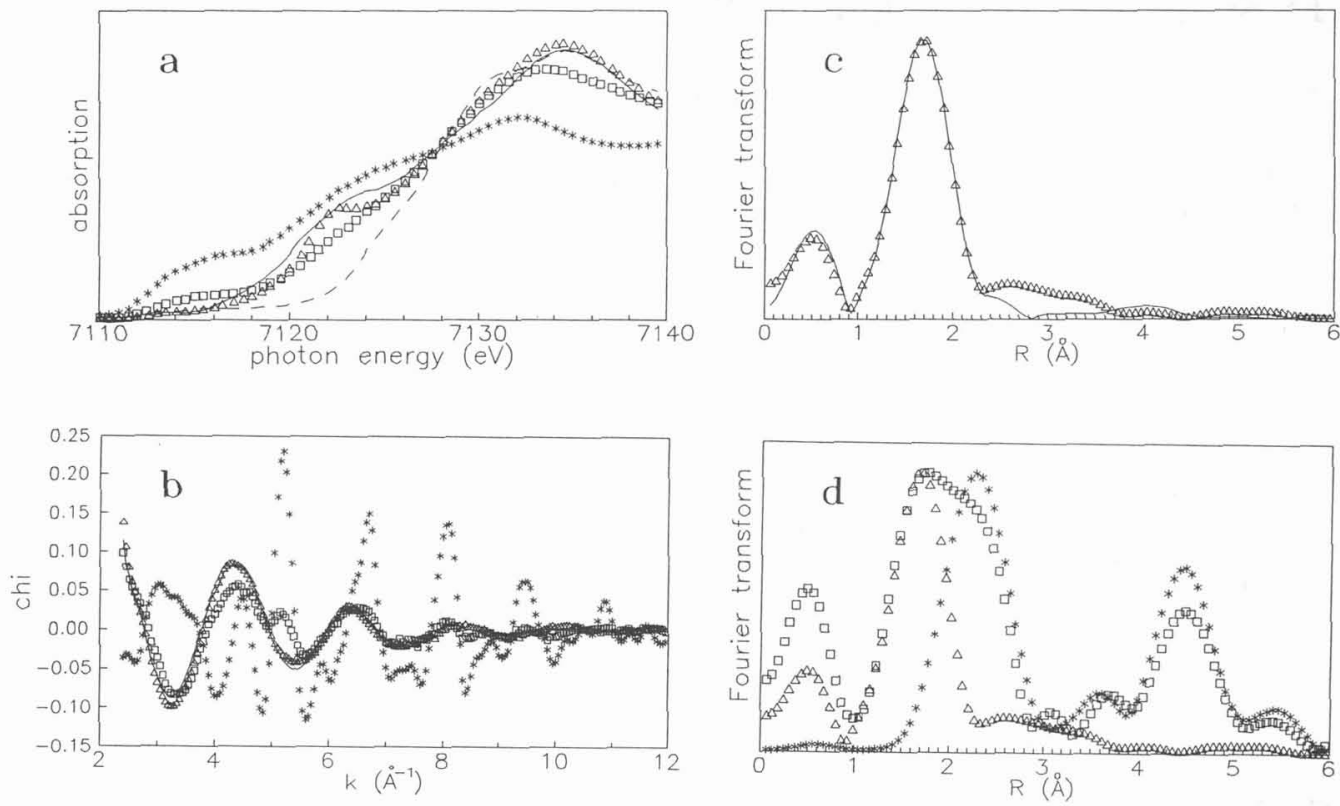

Figure 1: Results of XAFS studies of the monoclinic $\mathrm{C}_{60} \mathrm{Fe}_{2}$ fullerite (triangles), fcc $\mathrm{C}_{60} \mathrm{Fe}_{2}$ fullerite (squares), ferrocene (solid line), $\alpha \cdot \mathrm{Fe}$ (stars) and $\alpha-\mathrm{Fe}_{2} \mathrm{O}_{3}$ (dashes): (a) Fe K XANES spectra, (b) normalized EXAFS oscillations, (c, d) Fourier transforms.

The Fe K EXAFS spectra were analysed in a standard way. EXAFS oscillations of the monoclinic $\mathrm{C}_{60} \mathrm{Fe}_{2}$ and ferrocene are identical, while the EXAFS of fcc $\mathrm{C}_{60} \mathrm{Fe}_{2}$ demonstrates structure originated from a small contribution of iron particles (see Fig. lb). The Fourier transforms for the monoclinic $\mathrm{C}_{60} \mathrm{Fe}_{2}$ sample and ferrocene are presented in Fig. 1c. The main peak represents the nearest carbon neighbours around the Fe ion. Next carbon shells are visible in the FT of fullerite sample in contrast to that for ferrocene. No differences in FT moduli calculated for weighting factors $\mathrm{k}^{1}, \mathrm{k}^{2}$ and $\mathrm{k}^{3}$ were found, that is an evidence that the $\mathrm{Fe}$ atom has none $\mathrm{Fe}$ neighbours in the monoclinic $\mathrm{C}_{60} \mathrm{Fe}_{2}$ fullerite.

The FT curves of the monoclinic and fcc $\mathrm{C}_{60} \mathrm{Fe}_{2}$ fullerites and $\mathrm{Fe}$-metal were normalized to the main peak and compared in Fig, 1d. The double peak in the range of $1-3 \AA$ for fcc $\mathrm{C}_{60} \mathrm{Fe}_{2}$ fullerite is the evidence of the presence of the Fe-C and Fe-Fe neighbours shells. In addition three peaks in the range of 3.3-5.8 $\AA$ for fcc $\mathrm{C}_{60} \mathrm{Fe}_{2}$ fullerite are almost indentical to $\mathrm{Fe}$ metallic ones. The FT results show without doubt that in the fcc $\mathrm{C}_{60} \mathrm{Fe}_{2}$ fullerite small clusters of bcc $\mathrm{Fe}$ are present.

In summary, the $\mathrm{Fe} \mathrm{K}$-edge XAFS spectra have confirmed that in the monoclinic $\mathrm{C}_{60} \mathrm{Fe}_{2}$ only ions $\mathrm{Fe}^{2+}$ exist and the distances $\mathrm{Fe}-\mathrm{C}$ for the first atomic shells are identical in the monoclinic $\mathrm{C}_{60} \mathrm{Fe}_{2}$ and in ferrocene. The XAFS spectra have shown that any remarkable amount of neither Fe metallic clusters, nor oxidized iron particles are present in the monoclinic $\mathrm{C}_{60} \mathrm{Fe}_{2}$ sample. Additionally, the Fe K-edge XAFS spectra of the fcc $\mathrm{C}_{60} \mathrm{Fe}_{2}$ fullerite have shown that $\mathrm{Fe}$ neutral atoms, $\mathrm{Fe}{ }^{2+}$ and $\mathrm{Fe}^{3+}$ ions appear in this fullerite due to annealing at temperature $850 \mathrm{~K}$. The EXAFS study has proved the presence of small Fe clusters in this form of fullerite.

\section{Acknowledgments}

The authors thank Dr. D. Bonnin for the computer program for EXAFS analysis. This study was partly supported by the Committee for Scientific Research (grant No. 7T08A00308).

\section{References}

[1] Byszewski P., Diduszko R. and Kowalska E., "Preparation and properties of $\mathrm{C}_{60} \mathrm{Fe}_{2}$ solids", Recent Advances in the Chemistry and Physics of Fullerenes and Related Materials, San Francisco 25-29 August 1994, K.M. Kadish, R. S. Ruoff Eds. (The Electrochemical Society, Pennington, 1994) pp.1392-1401.

[2] Byszewski P., Kowalska E. and Diduszko R., J. Thermal Anal. 45 (1995) 1205-1210.

[3] Kucharski Z., Suwalski J. and Byszewski P., Materials Science Forum 191 (1995) 31-36. 